International Research Journal of Engineering, IT \& Scientific Research
Available online at https://sloap.org/journals/index.php/irjeis/
Vol. 7 No. 4, July 2021, pages: 116-125
ISSN: 2454-2261
https://doi.org/10.21744/irjeis.v7n4.1558

\title{
The Nursing Care Process in a User Diagnosed with Acinetobacter Baumannii
}

OrossMark $^{\text {Jazmin Isabel Choez Morán }}{ }^{\text {a }}$
Ronny Jair Baque Salazar $^{\mathrm{b}}$
Alexandra Denisse Torres Yampis $^{\mathrm{c}}$
María Belén Guerra Gómez $^{\mathrm{d}}$

Article history:

Submitted: 9 January 2021

Revised: 27 March 2021

Accepted: 18 April 2021

\section{Keywords:}

acinetobacter baumannii;

germs;

multi-resistant;

nursing care;

\begin{abstract}
This research work is conceived as the analysis of the nursing care process in a user with a diagnosis of Acinetobacter baumannii, for this the methodology used is descriptive, with a non-experimental qualitative approach, since a study is carried out on the records of the nursing care applied to a polytraumatized patient with a history of a car accident, admitted to the Intensive Care Unit from the operating room, and later diagnosed with infection by Acinetobacter Baumannii, for which a care plan based on NANDA taxonomies was developed, NOC and NIC emphasizing the hemodynamic and respiratory improvement, which allowed the patient to achieve a positive evolution, managing to discharge her to general hospitalization without ventilatory support.
\end{abstract}

International research journal of engineering, IT \& scientific research (C) 2021. This is an open access article under the CC BY-NC-ND license (https://creativecommons.org/licenses/by-nc-nd/4.0/).

\section{Corresponding author:}

Choez Morán, J. I. C.

Universidad Estatal del Sur de Manabí, Jipijapa, Ecuador

Email address: choez-jazmin1620@unesum.edu.ec

\footnotetext{
${ }^{a}$ Universidad Estatal del Sur de Manabí, Jipijapa, Ecuador

${ }^{\mathrm{b}}$ Universidad Estatal del Sur de Manabí, Jipijapa, Ecuador

${ }^{c}$ Universidad Estatal del Sur de Manabí, Jipijapa, Ecuador

${ }^{\mathrm{d}}$ Universidad Estatal del Sur de Manabí, Jipijapa, Ecuador 


\title{
1 Introduction
}

According to Zarate Grajales (2016) it is established that:.

\begin{abstract}
The notion of care is linked to the preservation or conservation of something or the assistance and help that is provided to another living being. The term derives from the verb to care (from the Latin coidar). Nursing, on the other hand, is associated with the care and monitoring of the state of a patient. Nursing is both this activity and the profession involved in performing these tasks and the physical place in which they are carried out. (p. $1)$.
\end{abstract}

In relation to the preceding description, it is determined that nursing care encompasses various attentions that a nurse must dedicate to his patient. Their characteristics will depend on the condition and severity of the subject, although at a general level it can be said that they are aimed at monitoring health and providing healthcare to the patient (Zarate Grajales, 2016). When a person is admitted to a hospital, nursing care will include serum control, monitoring of their vital parameters and the supply of medications indicated by the doctor, among other tasks (Zarate Grajales, 2016). On the other hand, in relation to Acinetobacter baumannii Vanegas Múnera (2015) refers that:

It is a species of gram-negative pathogenic coccobacillus bacteria, non-fermenting and resistant to most antibiotics. As a result of its resistance to drug treatment, some estimates claim that the disease kills a large number of patients per year. Disease caused by A. baumannii can cause severe pneumonia and urinary tract infections. (p. 2)

Among the most important risk factors for the development of an infection by this microorganism is the presence of invasive devices in the patient such as central catheters, endotracheal tubes, since the microorganisms adhere to these devices and subsequently invade the susceptible host developing the infectious process associated with health care (Vanegas Múnera, 2015). According to the antecedents exposed, the importance of conducting this study is denoted by virtue of the fact that this bacterium manifests a high multiresistance to antimicrobials, therefore, the relevance expressed around nursing care for this condition is distinguished in the procedures to perform, in order to ensure their quality and solve the symptoms manifested by the patient.

Acinetobacter baumannii is a huge problem and a global health challenge. It is one of the most common microorganisms in critically ill patients and causes serious infections such as ventilator-associated pneumonia or bacteremia. Its characteristics include its great adhesiveness, the ability to survive in the environment and the difficulty to eliminate it with the usual hygienic measures, which allows it to easily colonize surfaces and medical equipment (Zarate Grajales, 2016; Häyrinen et al., 2010; Jones et al., 2015).

Under this context and given the scientific medical connotations that this bacterium represents, various studies have been developed in which the proper care that should be given to patients who have contracted it is presented, so that some of these are detailed below with the purpose of providing the theoretical support necessary for the development of this research work.

Pérez Quintero (2018), through his article, distinguishes as a general objective the determination of the microbial load and typology related to infections associated with health care in clinical services, for which he carried out a descriptive quantitative study in the Surgical and Intensive Care service in A Hospital in Colombia determining that the Surgical service has a higher microbial load, the predominant germ being Acinetobacter baumannii, associated with the cleaning and disinfection processes of physical spaces and biomedical equipment (Pérez Quintero, 2018).

Through the study carried out by Yagüe Pasamón (2019), a nursing care plan for nosocomial pneumonia is established, this being a frequent complication associated with health care, which is caused among other multiresistant germs by Acinetobacter baumannii, distinguishing between the The main nursing care for this specific case, those related to the deterioration of gas exchange, the lack of self-care related to nutrition, the risk of deterioration of skin integrity and the control of hyperthermia (Yagüe Pasamón, 2019; Kalisch \& Lee, 2010; Liu et al., 2018).

The Pan American Health Organization (2017), through its publication, proposes measures for the control of multi-resistant germs, among which it stands out educating health personnel who participate in the care and treatment of colonized or infected patients about the mechanisms of transmission and relevance of compliance with the indicated measures, with periodic feedback on their compliance, this in relation to the control of Enterobacteriaceae with extended spectrum $\beta$-lactamase; Multiresistant Klebsiella pneumoniae, Pseudomonas aeruginosa and Acinetobacter baumannii (Pan American Health Organization, 2017). According to the research developed by Ortega Montero (2017), theis distinguished as one of the main nosocomial microorganisms Acinetobacter baumannii multiresistantPseudomonas aeruginosa resistant to carbapenems, also characterizing that it not only affects patients. who

Morán, J. I. C., Salazar, R. J. B., Yampis, A. D. T., \& Gómez, M. B. G. (2021). The nursing care process in a user diagnosed with acinetobacter baumannii. International Research Journal of Engineering, IT \& Scientific Research, 7(4), 116-125. https://doi.org/10.21744/irjeis.v7n4.1558 
are hospitalized but also people who are in the hospital environment such as health workers, service assistants, administrative staff, visitors, volunteers and support staff; For this reason, the use of protective barriers such as eye protectors, masks, gloves is essential, in addition to the application of biosafety standards such as hand washing with antiseptic soap, rubbing hands with alcohol (Ortega Montero, 2017; Tuinman et al., 2017; Tzeng et al., 2002).

\section{The nursing process and its stages}

The nursing care process corresponds to the application of the scientific method in nursing care practice, which allows care to be provided in a rational, logical and systematic way, which is vitally important for care quality to the patient. According to López Izuel (2016), it is determined that the process manages to delimit the specific nursing field that is the diagnosis and treatment of human responses, as well as the field of collaboration with other health professionals. It is therefore that, when applying due process, the nursing staff employs critical thinking, achieving professional satisfaction, providing holistic and individualized care, and engaging users in health care (López Izuel, 2016).

Patient assessment stage. - According to Carrasco (2018), this stage consists of collecting information about the patient and their state of health, as well as the family and community. In this regard, it is important to consider that the assessment must provide data corresponding to human and pathophysiological responses, therefore it requires the use of a nursing model or theory (Carrasco, 2018). According to the above, the steps to carry out the assessment are: data collection, validation, organization and communication. This is conceived as a continuous process that must be carried out during all the activities that the nursing staff does for and with the patient. Diagnostic stage. Regarding the diagnostic stage, Medina Moya (2018) refers that:

The system most used today to carry out nursing diagnoses is that of the NANDA (North American Nursing Diagnosis Association) diagnostic categories, for those health problems that are are within the specific field of nursing. It is important to differentiate a nursing diagnosis from an interdependent problem, both are health problems, but nursing diagnoses only refer to situations in which the nurse can act independently (p. 67).

The nursing diagnosis is a clinical judgment on the responses of the individual, family or community to real or potential health problems or life processes. Nursing diagnoses provide the basis for the choice of nursing actions, to achieve the results for which it is responsible. It is about the identification of a health problem, susceptible to be prevented, improved or resolved with nursing care (Medina Moya, 2018). Planning stage. Gutiérrez (2017), regarding the planning stage, states that:

\footnotetext{
It is the third stage of the process that begins after formulating the nursing diagnoses and interdependent problems. During this stage, care plans are drawn up that include: The health problem (nursing diagnosis or interdependent problem), objectives, independent and interdependent nursing actions and evolution (p. 76).
}

It is a requirement, during the planning stage, to define the priority to decide which health problems should be addressed first so as not to endanger the life of the user, and later to establish objectives focused on their family and community to solve the problem, as well as nursing actions that treat the etiology of the health problem (Gutiérrez, 2017). Execution stage. Within this stage Guerra (2017) distinguishes that it corresponds to the phase in which the actions of the nursing process are executed. During this stage, the response of the patient and the family to nursing care is identified. Priority should be given to helping patients gain independence and confidence in caring for their own needs. Recommendations when leaving the hospital are an important part of nursing interventions (Guerra, 2017).

From the assessment stage, information must be obtained on how to help the patient to be as self-sufficient as possible, within the environmental, physical and emotional limits of the moment in which they live. Some individuals require more information than others and the response to different educational methods is different. It is the faculty of the nursing staff to identify the needs of each person and provide the appropriate information to fill these significant knowledge gaps (Guerra, 2017).

Care evaluation stage. This stage of the nursing process, according to Alligood (2016) must be present during the execution of care, therefore, it is a continuous process that is defined as the planned and systematized comparison between the patient's health status and the results expected (Alligood, 2016). When measuring the progress of the patient towards the achievement of the objectives, the nursing staff assesses the effectiveness of the actions. On the other hand, it is distinguished that the evaluation process has two stages, which correspond to: 
- The collection of data on the patient's health status

- The comparison of the data collected with the expected results and the judgment on the evaluation of the patient towards the achievement of expected results

Acinetobacter baumannii Reyes Roque (2018) is its publication refers to:

\begin{abstract}
Acinetobacter baumannii is a pathogen that causes great impact in terms of public health, their ability to develop multidrug resistance, why in In the last 20 years, it has become one of the most relevant nosocomial pathogens, and is the cause of numerous epidemics in hospitals around the world, especially affecting critical patients admitted to the intensive care unit (ICU) (page 1).
\end{abstract}

Members of the genus Acinetobacter are characterized by being encapsulated, nonmotile, aerobic gram-negative bacilli, which may appear to be coccoid in their stationary growth phase, in addition to being oxidase negative, do not reduce nitrates, are indole negative, catalase positive, and lack Colour. The colonies measure 1 to $2 \mathrm{~mm}$ and are apigmented, dome-shaped and mucoid with smooth surfaces or with multiple pits, they are also ubiquitous with a great capacity to survive in different hosts and on inert surfaces, which gives them a greater capacity for dissemination., are free-living and can reside in animals and inanimate objects, although the main reservoir of Acinetobacter is humans (Reyes Roque, 2018). In this regard, according to Lemos (2019), it is determined that almost $100 \%$ of the soil and water samples develop the microorganism, so that any humid hospital environment, such as containers for ice, multi-dose vials, running water, vases, humidifiers, ventilation equipment, laryngoscope blades, curtains, skin of health personnel, mattresses, cushions and other equipment, which can serve as an environmental reservoir once it is contaminated (Lemos, 2019).

The survival capacity of this microorganism on dry surfaces on average greater than 25 days, where it is usually multi-resistant and its behavior is associated with health care. Its ability to form biofilms allows constant growth under unfavorable environmental conditions, a characteristic that gives it long survival. Rada Accounts (2016) states that:

\footnotetext{
There are factors that increase the risk of infection, such as: stay in the ICU, advanced age, immunosuppression, burns, invasive procedures, oro-tracheal intubation associated with mechanical ventilation, recent surgery and antimicrobial treatment previous. Diabetes mellitus, chronic renal failure, and inadequate antimicrobial treatment are predictors of a poor prognosis. The bacteria are not found in the air, but are spread through direct contact with contaminated surfaces, objects, or people's skin (p. 4).
}

In this regard, it is important to decontaminate objects close to the patient by spreading secretions from the ventilator circuit or by hand contact with contaminated sites. Hand colonization occurs between $3 \%$ and $30 \%$ of health professionals, of whom Acinetobacter baumannii has been isolated in $7.5 \%$, and it is also frequently the cause of ventilator-associated pneumonia during healthcare, skin infections and soft tissues, urosepsis, secondary meningitis and bacteremia (Rada Accounts, 2016).

According to Paciel (2018), it is established that current knowledge suggests that bacterial resistance is favored by multiple factors related to previous hospitalizations in the last year, prolonged hospital stays, invasive interventions such as surgeries or mechanical ventilation, advanced age, infections associated with health care, concomitant infection with HIV, and especially the misuse of antibiotics, such as aminoglycosides, quinolones, carbapenems, so that an adequate diagnostic evaluation of Acinetobacter baumannii isolates avoids the use of treatments Unnecessary antimicrobials that can lead to resistance (Paciel, 2018). Infection prevention and control measures are of particular importance and include: hand hygiene, patient placement, barrier precautions, aseptic practices, proper use of antimicrobials, sterilization and disinfection, environmental hygiene, and waste management. When outbreaks occur, it is necessary to monitor patient cultures and use additional antibiotic restriction policies to decrease resistance.

\title{
2 Materials and Methods
}

The development of this research work, due to its level, is guided by the guidelines established in the descriptive type, which Albareda (2017) refers to as the one in charge of "describing the population, situation or phenomenon around which focuses his study. It tries to provide information about the what, how, when and where, related to the research problem, without giving priority to answering the "why" of the problem" (p. 65). In this way, the present

Morán, J. I. C., Salazar, R. J. B., Yampis, A. D. T., \& Gómez, M. B. G. (2021). The nursing care process in a user diagnosed with acinetobacter baumannii. International Research Journal of Engineering, IT \& Scientific Research, 7(4), 116-125. https://doi.org/10.21744/irjeis.v7n4.1558 
study concerns the analysis of the nursing care process in a user with a diagnosis of Acinetobacter baumannii, that is, procedures and treatments used without investigating the causes that led to said diagnosis.

According to the type of research described, the approach provided for this work corresponds to the qualitative one, being this defined by Hernández Sampieri (2014), as "a descriptive data collection technique that is used to discover details that help explain behavior. It transmits the richness of people's thoughts and experiences "(page 9), under this premise this study is characterized by an analysis of the procedures carried out in relation to nursing care based on the diagnosis of Acinetobacter baumannii, a through documentary review. According to the degree of manipulation of the variables, this research is constituted as non-experimental, which is defined by Cegarra Sánchez (2018) as "one that is carried out without deliberately manipulating variables. It is fundamentally based on the observation of phenomena as they occur in their natural context in order to analyze them later "(p. 92). Under this context, no reagent is applied that modifies the main variables that make up the proposed research topic.

\section{Results and Discussions}

Presentation of the case: 34-year-old female patient with a history of a car accident, admitted to the Intensive Care Unit from the operating room, after an exploratory laparotomy operation, fixation of the right femur due to exposed fracture and head trauma severe. According to the questioning of relatives, the patient does not have a personal pathological history, they refer to alcohol and tobacco consumption in a social way. Upon admission to the ICU, prophylactic antibiotic treatment with third-generation cephalosporin and clindamycin was started. Laboratory results: $\mathrm{Hb} 10.10 \mathrm{~g} / \mathrm{dL}$, platelets 429,000 mm3 and leukocytes 17,000 uL. At 7 days of stay in the ICU, cultures of catheter, wound and bronchial secretion were performed, resulting positive for Acinetobacter Baumannii. Table 1 shows the values of the functional patterns.

Table 1

Assessment of functional patterns

\begin{tabular}{|c|c|}
\hline Patterns & Assessment \\
\hline Health perception & Not assessable \\
\hline Nutritional - metabolic & Presents overweight, body mass index $26.4 \mathrm{~kg} / \mathrm{m}^{2} . \mathrm{He}$ is fasting. \\
\hline Elimination & $\begin{array}{l}\text { Presents size } 16 \text { Foley-type bladder catheter, with no urinary output } \\
\text { present at the time of evaluation. Renal function (creatinine, blood urea } \\
\text { nitrogen and urea) within acceptable parameters, presenting a negative } \\
\text { fluid balance upon leaving the operating room. }\end{array}$ \\
\hline Activity - exercise & $\begin{array}{l}\text { Ventilatory support by endotracheal cannula, well ventilated lung fields } \\
\text { with crackles, presents multiple abrasive lesions in the chest, body } \\
\text { temperature of } 38.7^{\circ} \mathrm{C} \text {, heart rate of } 123 \mathrm{x} \text { ', respiratory rate of } 34 \mathrm{x} \text { ', } \\
\text { blood pressure of } 87 / 46 \mathrm{mmHg} \text {, mean arterial pressure of } 58 \text {, dependent } \\
\text { on norepinephrine at } 0.4 \mathrm{mcg} / \mathrm{kg} / \mathrm{min} \text {, clean surgical wound, with well- } \\
\text { faced edges, right pelvic limb with splint, showing capillary filling of } 4 \\
\text { seconds. It is in absolute rest. }\end{array}$ \\
\hline Sleep - rest & $\begin{array}{l}\text { Under the effects of sedation, with midazolam at } 18.5 \mathrm{mcg} / \mathrm{kg} / \mathrm{min} \text {, } \\
\text { fentanyl at } 18.5 \mathrm{mcg} / \mathrm{kg} / \mathrm{min} \text { and propofol at } 27.7 \mathrm{mcg} / \mathrm{kg} / \mathrm{min} \text {. }\end{array}$ \\
\hline Cognitive - perceptual & $\begin{array}{l}\text { Richmond agitation and sedation scale of }-4 \text {, anisochoric pupils (left }= \\
2 \mathrm{~mm} \text {, right }=4 \mathrm{~mm} \text { ). }\end{array}$ \\
\hline Self-perception - self-concept & Not assessable \\
\hline Role - relationships & Lives in her own home, married with 3 children. \\
\hline Sexuality - Reproduction & Not assessable \\
\hline Stress tolerance & Not assessable \\
\hline Values - beliefs & Not assessable \\
\hline
\end{tabular}

Table 2 shows the nursing care plan for patient patients with infection by Acinetobacter baumannii 
Table 2

Nursing care plan

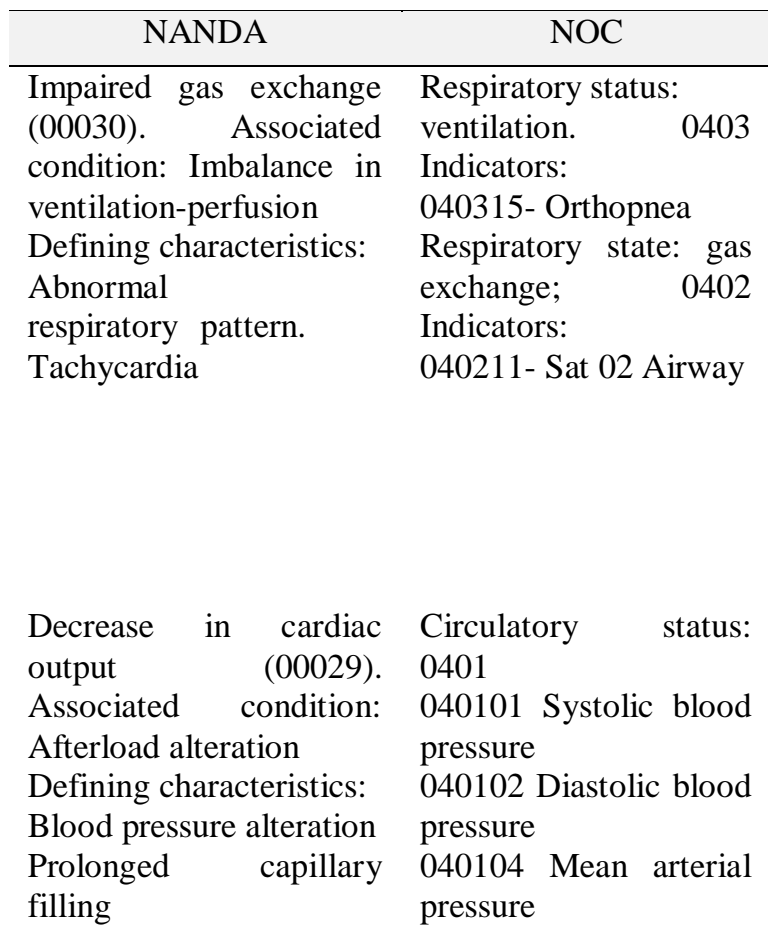

Risk of injury (00035).

Risk factors: In-hospital infection

Exposure to pathogens Associated condition Alteration in psychomotor functioning Population at risk: Impairment of primary defense mechanisms
Risk control:

1902

Indicators:

190202 Controls environmental risk factors 190204 Develops effective risk control strategies

\section{management 3140}

Activities:

- Position the patient to maximize ventilation potential

- Auscultate breath sounds, observing areas of decreased or absent ventilation and the presence of adventitious sounds

Mechanical ventilation management: invasive 3300

Activities:

- Control the conditions that indicate the need for ventilatory support.

- Control activities that increase the consumption of 02

Cardiac care 4044

Activities:

- Perform a comprehensive assessment of peripheral circulation.

- Monitor cardiovascular status.

- Fluid handling 4120

- Monitor hydration status

- Monitor hemodynamic status, including PVC, MAP, PAP, and PECP levels.

Isolation 6630

Activities:

- Designate a member of the nursing staff to communicate with the patient and direct the rest of the staff.

- Monitor the temperature, cleanliness and safety of the isolation area.

Infection control 6540

Activities:

- Clean the environment properly after each use by patients.

- Isolate people exposed to communicable diseases. Apply appropriate designated isolation precautions.

Artificial airway management 3180 Activities:

- Aspirate trachea, oral cavity, and then nasopharynx to clear secretions above the balloon of the ET tube to reduce the risk of aspiration.

- Maintain inflation of the endotracheal tube balloon at $15-20 \mathrm{~mm} / \mathrm{Hg}$ during mechanical ventilation

- Auscultate the presence of bilateral lung sounds

- Maintain the head of the bed elevated at 30-45

- Check the color, quantity and consistency of secretions Perform physiotherapy thoracic

Morán, J. I. C., Salazar, R. J. B., Yampis, A. D. T., \& Gómez, M. B. G. (2021). The nursing care process in a user diagnosed with acinetobacter baumannii. International Research Journal of Engineering, IT \& Scientific Research, 7(4), 116-125. https://doi.org/10.21744/irjeis.v7n4.1558 


\begin{tabular}{ll}
\hline hyperthermia (00007). & Severity of infection: \\
Related factors: & 0703 Indicators: \\
Dehydration & 070307 Fever 070335 \\
Defining characteristics: & Colonization of the \\
Skin hot to the touch & vascular access \\
Tachycardia & \\
Associated condition: & \\
Trauma &
\end{tabular}

Bath 1610

Activities:

Bath with water at a comfortable temperature.

Temperature regulation 3900

Activities:

- Establish a continuous core temperature monitoring device.

- Use ice or gel packs

- Adjust the ambient temperature to the needs of the patient

Management of a central venous access device 4054

- Use strict aseptic technique whenever the catheter is handled, accessed, or used to administer medication, with the in order to reduce catheter-related blood infections.

- Use needleless devices to promote a closed system.

- Change liquid infusion sets every 72 hours.

- Inspect the entry site daily for erythema, pain, tenderness, warmth, or swelling, as devices are associated with an increased risk of infection.

Source: NANDA, NOC and NIC. Prepared by: Prepared by the author

Evaluation: After the nursing care plans, the patient showed signs of improvement in her hemodynamic status, using the antibiotic Ceftazidime with Avibactam as antibiotics, reducing the infection; The recommendations of the evidence regarding isolation measures, surveillance and cleaning of the area were also followed, thus avoiding the risk of cross-infection and the patient was discharged to general hospitalization without ventilatory support. From the information contained in this document, it should be noted that the patient's consent was obtained to carry out the respective analysis.

This case study corresponds to the analysis of nursing care according to the evolution of a 34-year-old polytraumatized patient who was admitted to the Intensive Care Unit and was subsequently diagnosed withinfection Acinetobacter Baumannii. As a basis in relation to what is described, Pérez Quintero (2018), through his article, carried out a descriptive quantitative study in the Surgical and Intensive Care service in a Hospital, determining that in the Surgical service it has a higher microbial load, being the predominant germ the Acinetobacter baumannii, associated with the cleaning and disinfection processes of physical spaces and biomedical equipment. Under this context, a care plan based on the NANDA, NOC and NIC taxonomies was developed and executed, where emphasis was placed on improving the hemodynamic and respiratory status of the patient since her life and function were compromised, in addition to wound care surgical procedures and catheters (Pérez Quintero, 2018).

It is important to mention that patients hospitalized in the ICU, under mechanical ventilation and prolonged stay, constitute a population at risk of developing a pathology associated with Acinetobacter Baumannii, which is related to that referred by Álvarez Lerma (2016) who, through his study carried out In an Intensive Care Unit it is determined that the predominant species of microorganisms in critically ill patients corresponds to Acinetobacter Baumannii, this being the most frequent cause of infections in critically ill patients admitted to the ICU, which is why it must be considered as a highly pathogen virulence and propose its empirical coverage early in those ICUs and clinical situations in which its presence is possible (Álvarez Lerma, 2016). Infection Acinetobacter Baumannii requires a set of interventions in which the multidisciplinary health team participates to avoid cross-infection and reduce the risk of new outbreaks; the nursing professional plays an important role in participating in health education. Thus, Yagüe Pasamón (2019), through his study, establishes a nursing care plan for nosocomial pneumonia which is caused, among other multiresistant germs, by Acinetobacter baumannii, referring to the main nursing care for this specific case, those related to the deterioration of gas exchange, the deficit of self-care related to nutrition, the risk of deterioration of skin integrity and the control of hyperthermia (Yagüe Pasamón, 2019). 
Through the analysis carried out, nursing care was identified based on the NANDA, NOC and NIC taxonomies where it was emphasized to improve the hemodynamic and respiratory status of the patient in addition to the care of surgical wounds and catheters, it is thus according to the records after the application of the care plan to the patient, she recovered her hemodynamic status, using Ceftazidime with Avibactam as an antibiotic, which managed to reduce the infection; In addition, the recommendations of the evidence regarding isolation measures, surveillance and cleaning of the area were followed, thus avoiding the risk of cross-infection and the patient was discharged to general hospitalization without ventilatory support.

\section{Conclusion}

According to the research carried out, it was determined that the nursing process is conceived as the scientific method for nursing care practice, which provides the necessary knowledge to provide care in a rational, logical and systematic way, which is vitally important for quality care for patients. patient; For this, five stages are defined in the care process, which correspond to: 1) The assessment of the patient, which consists of collecting information about the patient's health, family and community; 2) Diagnosis, for which the NANDA diagnostic categories are commonly used; 3) Planning in which the care plans that integrate the health problem, the objectives, the nursing actions and evolution are elaborated; 4) Execution of the plans developed while identifying the response of the patient and the family; and, 5) Care evaluation that consists of a continuous process of planned and systematized comparison between the patient's health status and the expected results. According to the information collected, it is established that Acinetobacter baumannii is a multi-resistant pathogen and is the cause of numerous epidemics in hospitals around the world, especially affecting critical patients admitted to the Intensive Care Unit as well as in Surgical areas; The factors that increase the risk of infection include stay in the ICU, advanced age, immunosuppression, burns, invasive procedures, oro-tracheal intubation associated with mechanical ventilation, recent surgery and previous antimicrobial treatment.

\section{Conflict of interest statement}

The author(s) declared that they have no competing interest.

\section{Statement of authorship}

The author(s) have a responsibility for the conception and design of the study. The author(s) have approved the final article.

\section{Acknowledgments}

The authors thank the tutor professor Dra. María del Rosario Herrera Velázquez, for the support given during the research process.

Morán, J. I. C., Salazar, R. J. B., Yampis, A. D. T., \& Gómez, M. B. G. (2021). The nursing care process in a user diagnosed with acinetobacter baumannii. International Research Journal of Engineering, IT \& Scientific Research, 7(4), 116-125. https://doi.org/10.21744/irjeis.v7n4.1558 


\section{References}

Albareda, JM (2017). Consideraciones sobre la investigación científica. Madrid, España: Editorial Vita Brevis.

Alligood, M. (2016). Modelos y teorías en enfermería. Barcelona, España: Elsevier España, SL

Álvarez Lerma, F. (2016). Infecciones por Acinetobacter en pacientes críticos en UCI. Recuperado el 20 de diciembre de 2020, de Revista Elsevier, Enfermedades Infecciosas y Microbiología Clínica: https://www.elsevier.es/es-revista-enfermedades-infecciosas-microbiologia-clinica-28-articulo-infecciones-poracinetobacter-spp-pacientes- 13080263

Carrasco, E. (2018). Tutorial de enfermería. Madrid, España: Editorial CEP, SL

Cegarra Sánchez, J. (2018). Metodología de la investigación científica y técnológica. Madrid, España: Ediciones Díaz de Santos SA

Guerra, C. (2017). El proceso de atención de enfermería. Barranquilla, Colombia: Editorial Universidad del Norte (Colombia).

Gutiérrez, E. (2017). El proceso de enfermería: una metodología para la práctica. Madrid, España: Editorial Médica Panamericana.

Häyrinen, K., Lammintakanen, J., \& Saranto, K. (2010). Evaluation of electronic nursing documentation-Nursing process model and standardized terminologies as keys to visible and transparent nursing. International journal of medical informatics, 79(8), 554-564. https://doi.org/10.1016/j.ijmedinf.2010.05.002

Hernández Sampieri, R. (2014). Metodología de la investigación. México: McGraw-Hill - Interamericana Editores, $\mathrm{SA}$ de $\mathrm{CV}$

Jones, T. L., Hamilton, P., \& Murry, N. (2015). Unfinished nursing care, missed care, and implicitly rationed care: State of the science review. International journal of nursing studies, 52(6), 1121-1137. https://doi.org/10.1016/j.ijnurstu.2015.02.012

Kalisch, B. J., \& Lee, K. H. (2010). The impact of teamwork on missed nursing care. Nursing outlook, 58(5), 233241. https://doi.org/10.1016/j.outlook.2010.06.004

Lemos, E. (2019). Mortalidad por Acinetobacter baumannii en unidades de cuidados intensivos en Colombia. Recuperado el 07 de diciembre de 2020, de Revista Panamericana de Salud Pública: https://www.scielosp.org/article/rpsp/2011.v30n4/287-294/

Liu, X., Zheng, J., Liu, K., Baggs, J. G., Liu, J., Wu, Y., \& You, L. (2018). Hospital nursing organizational factors, nursing care left undone, and nurse burnout as predictors of patient safety: A structural equation modeling analysis. International journal of nursing studies, 86, 82-89. https://doi.org/10.1016/j.ijnurstu.2018.05.005

López Izuel, C. (2016). Cuidados enfermeros. Barcelona, España: Editorial Masson, SA

Medina Moya, JL (2018). Enfermero/a. Servicios de salud. Madrid, España: Editorial CEP, SL

Organización Panamericana de la Salud. (2017). Prevención y control de infecciones asociadas a la atención de la salud. Recomendaciones básicas. Recuperado el 07 de diciembre de 2020, de Sitio Web de la Organización Panamericana de la Salud: https://www.hsmq.cl/wp-content/uploads/2018/06/Prevencion-IAASRecomendaciones-Basicas.pdf

Ortega Montero, DA (2017). Estrategias de atención de enfermería y su influencia en infecciones nosocomiales de pacientes hospitalizados en la unidad de cuidados intensivos del Hospital General Docente Ambato. Recuperado el 05 de diciembre de 2020, de Repositorio Digital de la Universidad Regional Autónoma de los Andes UNIANDES: http://dspace.uniandes.edu.ec/bitstream/123456789/6045/1/PIUAENF017-2017.pdf

Paciel, D. (2018). Tratamiento de Acinetobacter spp extremadamente resistente (XDR) y panresistente (PR). Recuperado el 07 de diciembre de 2020, de Repositorio de la Universidad de la República (UDELAR): http://www.infectologia.edu.uy/images/archivos/Esquemas_Tto_Acineto_XDR.pdf

Pérez Quintero, C. (2018). Carga y tipología microbiana relacionada con infecciones asociadas a la asistencia sanitaria en servicios clínicos. Recuperado el 07 de diciembre de 2020, de Revista Cubana de Enfermería: http://www.revenfermeria.sld.cu/index.php/enf/article/view/1643/402

Rada Cuentas, J. (2016). Acinetobacter un patógeno actual. Recuperado el 07 de diciembre de 2020, de Revista de la Sociedad Boliviana de Pediatría: http://www.scielo.org.bo/pdf/rbp/v55n1/v55n1_a06.pdf

Reyes Roque, AC (2018). Acinetobacter baumanni: amenaza para la salud humana. Recuperado el 07 de diciembre de 2020, de Revista Archivo Médico de Camagüey: http://scielo.sld.cu/pdf/amc/v22n6/1025-0255-amc-22-06695.pdf

Tuinman, A., de Greef, M. H., Krijnen, W. P., Paans, W., \& Roodbol, P. F. (2017). Accuracy of documentation in the nursing care plan in long-term institutional care. Geriatric nursing, 38(6), 578-583. https://doi.org/10.1016/j.gerinurse.2017.04.007 
Tzeng, H. M., Ketefian, S., \& Redman, R. W. (2002). Relationship of nurses' assessment of organizational culture, job satisfaction, and patient satisfaction with nursing care. International journal of nursing studies, 39(1), 79-84. https://doi.org/10.1016/S0020-7489(00)00121-8

Vanegas Múnera, JM (2015). Acinetobacter baumannii: importancia clínica, mecanismos de resistencia y diagnóstico. Recuperado el 07 de diciembre de 2020, de Revista CES Medicina: http://www.scielo.org.co/pdf/cesm/v28n2/v28n2a08.pdf

Yagüe Pasamón, R. (2019). Cuidados de enfermería al paciente con neumonía nosocomial complicada. Plan de cuidados estandarizado. Recuperado el 07 de diciembre de 2020, de Revista Electrónica de Portales Medicos: https://www.revista-portalesmedicos.com/revista-medica/cuidados-de-enfermeria-al-paciente-con-neumonianosocomial-complicada-plan-de-cuidados-estandarizado/

Zarate Grajales, RA (2016). La Gestión del Cuidado de Enfermería. Recuperado el 07 de diciembre de 2020, de Index de Enfermería: http://scielo.isciii.es/scielo.php?script=sci_arttext\&pid=S1132-12962004000100009.

Morán, J. I. C., Salazar, R. J. B., Yampis, A. D. T., \& Gómez, M. B. G. (2021). The nursing care process in a user diagnosed with acinetobacter baumannii. International Research Journal of Engineering, IT \& Scientific Research, 7(4), 116-125. https://doi.org/10.21744/irjeis.v7n4.1558 